\title{
Impact of IFRS on Deferred Taxes Methodology in the Czech Republic and comparison with IFRS for SMEs
}

\author{
Marcela ŽÁROVÁ*
}

\section{Introduction}

IFRS, in the last decade, has not only strategic impact on the architecture of particular European accounting systems but it is also assumed that IFRS brings positive impact on the quality of local accounting rules. However, there may be difficulties in applying international standards in a local context (Žárová, 2006). Drawing on evidence of deferred taxes regulation in the Czech Republic, this article demonstrates the problem of the partial introduction of IFRS into European local accounting systems. Based on the criticism of partial implementation of IAS 12 into local accounting rules, this article is focused on comparability of Czech accounting rules for deferred taxes with IFRS for SME.

Conclusion from this investigation might become fundamentals for similar European accounting systems to the Czech Republic, where regulatory policy has been realized over last 20 year by regulatory institutions in Europe and despite the harmonization process, there may be systematically different patterns of accounting behavior applicable to various groups of countries (Radebaugh, 2006, p. 34).

\footnotetext{
\# The article is processed as an output of a research project Development of Financial and Accounting Theory and its Application in Practice from Interdisciplinary Point of View, registered by the Grant Agency under the registration provider's code MSM, RP identification code 6138439903.

Doc. Ing. Marcela Žárová, CSc. - Associate professor; Department of Financial Accounting and Auditing, Faculty of Finance and Accounting, University of Economics, Prague, W.Churchill Sq.4, 13067 Prague 3; Czech Republic; <zarova@ vse.cz>.
} 


\section{Impact of IFRS on introduction of deferred taxes into the Czech accounting system}

The Czech regulatory accounting system since early ninetieth till 2002 is characterized as an accounting regulation without hierarchy, a "legal level," or one-level accounting regulation. From a legal point of view, accounting regulation consisted of the Act only. The Ministry of Finance issued detailed Regulatory guidance for accounting which consisted of a Chart of accounts and Accounting procedures. Even though Regulatory guidance for accounting was not part of the Act, it became obligatory as it was strictly required by tax authorities in the Czech Republic (Žárová, 2008). In addition to financial statements prepared in compliance with the Act on Accounting, accounting units may also provide accounting information those are prepared in compliance with IFRS or other internationally recognized accounting principles.

Changes to the regulatory framework were completed as of January 1, 2004. Regulatory framework was enlarged into three separate levels. Czech Accounting Standards superseding the Regulatory guidance for accounting came into force. A new phenomenon in Czech accounting, Czech Accounting Standards, was introduced by the legislator. There is a separate article in the Act determining who is allowed to develop National Accounting Standards. The article determines Ministry of Finance or any legal entity selected in public tender. In January 2004, Czech Accounting Standards came into force. Czech Accounting Standards superseded the Provision of the Ministry of Finance. Traditionally, institutions developing accounting standards are independent professional accounting bodies, nowadays governmental agencies becomes standard setters and developed quasi standards. Similar development of the primary hybrid regulatory accounting system will may to be expected in the Czech Republic as the article of the Act determines Ministry of Finance or any legal entity selected in public tender as a standard setter. This is historically the first moment when Ministry of Finance in the Czech Republic admits the possibility of existence a rule-making body that differs from Ministry of Finance. These regulatory accounting systems, where accounting system combines elements of private and public standards setting and independent professional accounting bodies with governmental institutions could be called hybrid regulatory ones (Žárová, 2007).

Investigating impact of IFRSs on the accounting regulatory system in the Czech Republic, there should be highlighted that IFRS were 
introduced into the regulatory system gradually as a separate regulatory system for determined group of accounting entities, on the other hand IFRSs have had influence on the development of the local accounting rules during last decade.

In the period covering 1991-2002, "In addition to financial statements prepared in compliance with the Act on Accounting, accounting units may also provide accounting information those are prepared in compliance with IFRS or other internationally recognized accounting principles."

In the period covering the year 2003, there was no change in using IAS from previous amendment of the Act on Accounting and accounting units were allowed to use besides domestic rules IAS or other internationally recognized accounting principles.

In the period covering the 2004 till 2011, there was substantial change in using and implementation of IFRS. The year 2004 became crucial historical moment in the existence of the Czech Republic, also in accounting regulation. In May, 2004, the Czech Republic joined the European Union (EU). Adoption of the 2002 EU Regulation on the application of IFRS had fundamental effects on further development of accounting rules in the Czech Republic. Since joining the EU all listed companies shall prepare at least their consolidated financial statements in accordance with IASC standards by 2005 at the latest. The Accounting act dealing systematically with obligation to use of IFRS was issued firstly in the year 2004 .

In the period starting in the year 2011, there is an amendment of Act on Accounting. Since 2011, companies specified by the Act are allowed to select IFRSs as the basis for preparation of individual financial statements (parent companies preparing consolidated financial statements in compliance with the IFRS voluntarily, accounting entities under the control belonging to a consolidation group for which consolidating company prepares IFRS consolidated financial statements, joint ventures belonging to a consolidation group for which consolidating company prepares IFRS consolidated financial statements);(Žárová - Procházka Roe, 2011, p. 48).

In late ninetieth, the issue of deferred taxes was opened for the first time. However, the whole procedure was extremely limited as for the 
accounting entities referred to and as for the scope of timing differences giving rise to deferred taxes too. Regulatory guidance for accounting contented procedures concerning deferred taxes, where only those entities in a group were accounted for deferred taxes. Moreover, only the differences between taxable income and accounting profit arising from any different between tax and accounting depreciation of both tangible and intangible long-term assets were title for deferred tax recognition. This was rather unique situation and it was criticised by accounting practitioners. Firstly only entities in group were obliged to report deferred taxes and secondly only when differences between taxable income and accounting profit arising from any different between tax and accounting depreciation of both tangible and intangible long-term assets. Despite the criticism, companies fulfilled only the statutory requirements. With respect of this procedure, only entities in group provided users of financial statements with true and fair view.

Used method for deferred taxes wasn't described, but it could be deduced from the recognition of timing differences and from the applicability of future tax rates, that it was using the income statement liability method. Moreover, the outcome deferred tax asset or deferred tax liability was presented in the balance sheet either as a current asset or a current liability. Deferred tax recognition as a short-term balance items are against principles in any accounting standards. The deferred tax asset was to be recognised only if there were no doubts about its future utilisation as the consequence of the principle of conservatism.

During the period 1990-2002, another major change in deferred taxes happened. In January 2001, the Accounting Act together with the Provision of the Ministry of Finance was amended in order to bring the Czech legislature closer to the IAS. The scope of deferred tax accounting was broadened and encompassed not only the timing differences arising from different tax and accounting depreciation, for which the recognition was compulsory, but also from other sources: for example product warranty costs, provisions, valuation allowances and loss carried forwards, which were to be recorded at an entity's discretion. Another significant change was the introduction of the balance sheet liability method for the accounting of deferred taxes on the first-time adoption, but only in this one moment! Again this was not explicitly stated in the Act or Regulatory guidance for accounting, for that matter, but was evident from the way in which the carrying amounts of individual items were regarded. 
There was a radical change from the previous requirements in the Regulatory guidance ${ }^{1}$ January 2002 . It extended the number of entities for which recognising deferred taxes became mandatory: not only the entities forming a group, but also those which had to have their financial statements audited. The others were allowed but not required to account for deferred taxes (Filinger, 2009). Companies which has obligation to prepare financial statement in compliance with IFRS has obligation to keep their accounts in compliance with IFRS as well. IFRS substitute domestic rules completely. Companies either use IFRS or Czech rules for keeping their accounts and for reporting in financial statements. The reformation of the accounting regulation was completed during the year 2003. Since January 2004, the new hierarchy of domestic rules consists of Act on Accounting, Decrees ${ }^{2}$, Czech Accounting Standards ${ }^{3}$.

In January 2002, the second major change concerning the deferred tax method used. There was move from the income statement to the balance sheet liability method, and so from timing to temporary differences. The change was finalized by introducing Decree into the regulatory hierarchy. Deferred taxes are described as a special accounting method in Decree on accounting for business entities which is in force since 2003. Decree introduced deferred tax in a separate section called method of deferred tax. In spite of the fact that this part is called "deferred tax method", the method is not explained here at all, the method is only entitled.

In compliance with the Decree, the entity is required to recognise deferred tax liability or asset for all taxable and deductible temporary differences. Deferred tax asset is recognised only to the extent that it is probable that future taxable income will be available and the only relevant source of the future taxable income is that of the reversals of taxable temporary differences relating to the same taxation authority and reversing in the periods to which the deductible temporary differences and/or losses can be carried back or forward. Then the way of deferred tax calculation is described. In compliance with IAS 12 (IASB 2009a), the decree uses balance sheet liability method. In this part of the decree, there is a stress on the fact that the calculation of deferred tax shall be

\footnotetext{
The Provision of MF No. 281/89 759/2001.

2 Decree on Accounting for Business No 500/2002 Col. as amended by Decree No. 472/2003Col., 397/2005 Col., 349/2007 Col. And 469/2008 Col.

3 Czech Accounting Standards 1-23 in effect as of January 1, 2009, issued by the Ministry of Finance in compliance with article 36 of Accounting Act No 563/1991 Coll. as amended by Act No 495/2005 Col.
} 
based on the liability method arising from the balance sheet approach. There is a note concerning the practical way of calculating the deferred tax, "where this future tax rate is not known, the tax rate in effect in the subsequent accounting period shall be used". And "The balance sheet aspect means that the liability method is based on temporary differences which are the differences between the tax base of assets, or (if relevant) liabilities, and the amount of assets, or (if relevant) liabilities, as shown in the balance sheet". Here the term temporary differences are mentioned firstly, but no other explanation than the note above is written. Moreover there is not mentioned any relation between timing differences determined in accordance with income statement liability method at all. The income statement liability method focuses on timing differences, whereas the balance sheet liability method focuses on temporary differences.

Beside the balance sheet liability method, other important rule was introduced, first-time application, under which an entity has to divide the resulting amount of deferred tax into two parts depending on their relation to the current and prior periods. In compliance with the division the deferred tax into current and prior period, to credit or charge them to current profit or loss and to retained earnings, respectively. This procedure should assure not to distort the amount of accounting profit or loss for the period. Any further changes in the method of accounting or tax consequences of capital transformations should also have been recognised directly in stockholders' equity. Relevant information concerning this fact should be disclosed in the notes to the financial statements. Since 2002, deferred tax assets and deferred tax liabilities balances were moved from current assets and current liabilities to longterm provisions. To long-term liabilities (not provisions, where they should be recognized) and to receivables those are divided into long-term and short term ones; into long-term receivables.

It was awaited by practitioners and academics too, that the process of deferred taxes reform will be finalized by issuing the Decree on accounting for business entities and by the Czech Accounting Standard on deferred taxes. But the reform as for deferred taxes was realized only partially and wasn't adopted a holistic approach of IFRS implementation into local national accounting regulatory system.

In the following text, there is description of partial IFRS deferred tax implementation. The tax base is introduced in the Decree but there is no 
definition of newly introduced terms. Deferred tax asset or deferred tax liability calculation are introduced. As for recognition of deferred tax liability and deferred tax asset, it is said that the accounting entity shall always account for a deferred tax liability and will account for a deferred tax asset, taking into consideration the prudent concept. Here is no detail in respect of reassessment of once unrecognised deferred tax assets settled, it is not incorporated into the Decree. There is no manner and scope of deferred tax disclosure. Despite the fact that Czech Accounting Standard on deferred taxes was issued, the shortages weren't eliminated.

The standard states that "deferred tax shall be computed on all temporary differences resulting from a different accounting and tax treatment of items shown in the books of account". This statement doesn't implies any exception from this rule. While the IAS 12 states that a deferred tax liability shall be recognised for all taxable temporary differences, except to the extent that the deferred tax liability arises from:(a) the initial recognition of goodwill; or (b) the initial recognition of an asset or liability in a transaction which is not a business combination; and at the time of the transaction, affects neither accounting profit nor taxable profit (tax loss).

The decree on deferred tax includes accounting procedure on:

- reassessment of unrecognised deferred tax assets which is in compliance with IAS 12 and states that at the end of each reporting period, an entity reassesses unrecognised deferred tax assets;

- rules for first time deferred tax adoption;

- changes of method;

- posting of deferred tax liability or deferred tax asset; - tax rate alteration: In the case that the income tax rate is altered, it is necessary to recalculate the balance in the account where deferred tax is followed and book the difference;

- temporary differences in business combination: Temporary differences may arise in a business combination. Fair value adjustments and revaluation of assets in a business combination or capital investment will give rise to differences which will result in a deferred tax (Skálová - Čouková, 2009, p. 161). The carrying value of assets shall be increased to the fair value but the tax base shall remain in the amount computed according to the original acquisition cost. Where differences in respect of such assets arise, 
the accounting entity shall include them in the calculation of deferred tax in the following way. In the case of items which are directly credited or debited against own equity (in acquiree's financial statements in business combination), a deferred tax shall also be directly posted as a credit or debit entry against own equity.

Very serious criticism is concerning the goodwill. The goodwill is completely omitted in Czech Accounting Standard. The topic of goodwill is important and for the purpose of goodwill recognition IAS 12 should be implemented. However, the rules stated in IAS 12 does not permit the recognition of the resulting deferred tax liability because goodwill is measured as a residual and the recognition of the deferred tax liability would increase the carrying amount of goodwill (Pelák, 2009). Still, the reasoning of IAS 12 that goodwill was a residual and any increase in its carrying amount, resulting from the recognition of a deferred tax liability, would not have been appropriate, is understandable and with the related goodwill definition also conceptually defendable (Filinger, 2009). The stumbling block is that recognition of goodwill in Czech accounting differs from IFRS approach and deferred taxes arise from business combination are not allowed to be account directly to goodwill, but in compliance with Czech Accounting Standard, into acquiree's equity.

Manner and scope of disclosures to the issue of deferred taxes are not involved in the Czech accounting standard as well as the fact that deferred tax assets and liabilities shall not be discounted in compliance with IAS 12 .

\section{Comparability of Czech accounting rules for deferred taxes with IFRS for SME}

This part of article is focused on comparability of Czech accounting rules for deferred taxes with IFRS for SMEs. Criticising introduction of IAS12 into the Czech accounting rules as for incompleteness, there might exist hypothetical compliance between Czech accounting rules for deferred taxes and IFRS for SMEs.

The IASB also develops and publishes a separate standard intended to apply to the general purpose financial statements of entities that in many countries are referred small and medium-sized entities (SMEs), private entities and non-publicly accountable entities. Frequently, the term SMEs 
is used for very small entities without regard to whether they publish financial statements for external users. SMEs often produce financial statements only for the use of owner-managers or only for the use of the authorities or other governmental authorities.

IFRS for SMEs provides with definition of SMEs "small and medium-sized entities are entities that (IASB, 2009b):

a) do not have public accountability, and

b) publish general purpose financial statements for external users."

External users for the purpose of SMEs standard include owners who are not involved in managing the business, existing and potential creditors, and credit rating agencies. if:

In compliance with IFRS for SMEs, an entity has public accountability

- its debt or equity instruments are traded in a public market or it is in the process of issuing such instruments for trading in a public market (a domestic or foreign stock exchange or an over-thecounter market, including local and regional markets), or

- it holds assets in a fiduciary capacity for a broad group of outsiders as one of its primary businesses. This is typically the case for banks, credit unions, insurance companies, securities brokers/dealers, mutual funds and investment banks.

IFRS for SME, in the section "Income tax" covers accounting for income tax, where tax amounts comprise current tax and deferred tax. The section is divided into several subsections; steps in accounting for deferred taxes, recognition of deferred taxes, measurement of deferred taxes, presentation and disclosure.

There is a clear description of the accounting process in the form of steps in the process of deferred taxes identification. Firstly it has to be identified which assets and liabilities would expected to affect taxable profit if they were recovered or settled for their present carrying amounts. Then there should be determined the tax basis at the end of the reporting period for the assets and liabilities that would expected to affect taxable profit. The tax basis of assets and liabilities is determined by the consequences of the sale of the assets or settlement of liabilities for their 
present carrying amounts and other items that have a tax basis although they are not recognised as assets or liabilities, ie items recognised as income or expense that will become taxable or tax deductible in future periods. Then temporary differences, unused tax losses and unused tax credits are to be computed. The following step is to recognise deferred tax assets and deferred tax liability arising from the temporary differences, unused tax losses and unused tax credits.

Measurement of deferred tax assets and liabilities is in the following section. Deferred tax assets and liabilities are measured at an amount that includes the effect of the possible outcomes of a review by the tax authorities using tax rates that, on the basis of enacted or substantively enacted tax law at the end of the reporting period, are expected to apply when the deferred tax asset is realised or the deferred tax liability is settled.

Then valuation allowance against deferred tax assets is recognised. Valuation allowance is recognised so that the net amount equals the highest amount that is more likely than not to be realised on the basis of current or future taxable profit.

Deferred tax is then allocated to the related components of profit or loss, other comprehensive income and equity. Last step is presentation and disclosure of the required information.

While the IFRS for SMEs in the section of deferred tax has in the opening part clear description of steps in the procedure of deferred tax accounting, the Czech Decree on accounting for business entities describes the deferred taxes as a special accounting method. The decree in this part concerns method used, deferred tax calculation, used tax rate, states the fact that balance sheet aspect of liability method is used based on temporary differences, conditions for deferred tax liability and deferred tax asset recognition, procedure of deferred tax first time recognition. There is no clear description of procedure.

Following the steps, recognition of deferred tax is divided into several subsections. The first part of this subsection comprises general recognition principle. Determination of general recognition principle seems to be crucial. There is a statement that an entity shall recognise a deferred tax asset or liability for tax recoverable or payable in future periods as a result of past transactions or events. Such tax arises from the 
difference between the amounts recognised for the entity's assets and liabilities in the statement of financial position and the recognition of those assets and liabilities by the tax authorities, and the carry forward of currently unused tax losses and tax credits. Investigating either the Czech Decree on accounting for business entities or Czech Accounting Standard No.3, there is an absence of deferred tax general recognition principle.

In the text, there is a very important note concerning assets and liabilities whose recovery or settlement will not affect taxable profit. If the entity expects to recover the carrying amount of an asset or settle the carrying amount of a liability without affecting taxable profit, no deferred tax arises in respect of the asset or liability. Therefore such procedures as determination of tax basis, determination of temporary differences and recognition of deferred tax liabilities and assets apply only to assets and liabilities for which the entity expects the recovery or settlement of the carrying amount to affect taxable profit and to other items that have a tax basis.

An entity shall determine the tax basis of an asset, liability or other item in accordance with enacted or substantively enacted law. Then the definition of tax basis is determined as the amounts that will be included in taxable profit on recovery or settlement of the carrying amount of an asset or liability. Tax basis is separately recognised for tax basis of an asset and tax basis of a liability (IASB, 2009b):

(a) the tax basis of an asset equals the amount that would have been deductible in arriving at taxable profit if the carrying amount of the asset had been recovered through sale at the end of the reporting period. If the recovery of the asset through sale does not increase taxable profit, the tax basis shall be deemed to be equal to the carrying amount.

(b) the tax basis of a liability equals its carrying amount less any amounts deductible in determining taxable profit (or plus any amounts included in taxable profit) that would have arisen if the liability had been settled for its carrying amount at the end of the reporting period. In the case of deferred revenue, the tax base of the resulting liability is its carrying amount, less any amount of revenue that will not be taxable in future periods.

Standard mentions items those have a tax basis but are not recognised as assets and liabilities. As an example, there are used research costs, 
which are recognised as an expense when they are incurred but may not be permitted as a deduction in determining taxable profit until a future period. Thus, the carrying amount of the research costs is nil and the tax basis is the amount that will be deducted in future periods. Another example is equity instrument issued by the entity, which may also give rise to deductions in a future period. There is no asset or liability in the statement of financial position, but the tax basis is the amount of the future deductions.

The Czech decree on deferred taxes includes statement "The tax base of such assets, or (if relevant) liabilities, shall be the value of these assets, or liabilities, which can be claimed for tax purposes in the future." In this part, tax base of an asset or tax base of a liability is firstly mentioned but there is no definition of newly introduced terms while IFRS for SMEs uses definition for tax base of an asset or tax base of a liability as "the amount attributed to that assets or liability for tax purposes."

Practical aspect of deferred taxation is recognition when temporary differences arise (IASB, 2009b). Temporary differences arise either

(a) when there is a difference between the carrying amounts and tax bases on the initial recognition of assets and liabilities, or at the time a tax basis is created for those items that have a tax basis but are not recognised as assets and liabilities or

(b) when a difference between the carrying amount and tax basis arises after initial recognition because income or expense is recognised in comprehensive income or equity in one reporting period but is recognised in taxable profit in a different period or

(c) when the tax basis of an asset or liability changes and the change will not be recognised in the asset or liability's carrying amount in any period.

Czech legislation mentions temporary differences in the third subsection of the decree. Differences which arise as a result of different accounting and tax treatment are of a temporary nature. Czech decree divides temporary differences into taxable and deductible.

IFRS for SMEs requires that an entity shall recognise deferred tax liabilities and assets with some exceptions. 
- a deferred tax liability for all temporary differences that are expected to increase taxable profit in the future.

- a deferred tax asset for all temporary differences that are expected to reduce taxable profit in the future.

- a deferred tax asset for the carry forward of unused tax losses and unused tax credits (IASB, 2009b).

IFRS for SMEs continues with a list of exceptions from the rules concerning recognition of deferred tax liabilities and assets:

- An entity shall not recognise a deferred tax asset or liability for temporary differences associated with unremitted earnings from foreign subsidiaries, branches, associates and joint ventures to the extent that the investment is essentially permanent in duration, unless it is apparent that the temporary difference will reverse in the foreseeable future.

- An entity shall not recognise a deferred tax liability for a temporary difference associated with the initial recognition of goodwill (IASB, 2009b).

The Czech decree also states that a temporary difference may arise on initial recognition of an asset or liability, for example if part or all of the cost of an asset will not be deductible for tax purposes. But the main obstacle in the Czech rules for deferred taxes seems to be the absence of clear determination of exception from the rules on initial recognition. Czech rules for deferred taxes only determine to recognise a deferred tax asset or liability for temporary differences for all temporary differences. As adjustments arises on initial recognition of an asset or liability would make the financial statements less transparent, IFRS does not permit an entity to recognise the resulting deferred tax liability or asset, either on initial recognition or subsequently. Furthermore, an entity does not recognise subsequent changes in the unrecognised deferred tax liability or asset as the asset is depreciated. This part concerning exception from the rule Czech accounting standard is missing at all.

IFRS for SMEs states that an entity shall recognise changes in a deferred tax liability or deferred tax asset as tax expense in profit or loss, except that a change attributable to an item of income or expense recognised under this IFRS as other comprehensive income shall also be recognised in other comprehensive income (IASB, 2009b). The IFRS for SMEs requirement on recognition a change attributable to an item of 
income or expense recognised under this IFRS as other comprehensive income would bring another obstacle into Czech accounting system. Financial reporting in the Czech accounting system doesn't introduce either comprehensive income statement or other comprehensive income.

Measurement of deferred tax is another part of IFRS for SMEs. Subsection measurement is divided into information on tax rates and valuation allowance. "An entity shall measure a deferred tax liability or asset using the tax rates and laws that have been enacted or substantively enacted by the reporting date". In the Czech Decree, there is a note concerning the practical way of calculating the deferred tax, "where this future tax rate is not known, the tax rate in effect in the subsequent accounting period shall be used".

The situation when different tax rates apply to different levels of taxable profit is treated by the IFRS for SMEs. "An entity shall measure deferred tax expense (income) and related deferred tax liabilities (assets) using the average enacted or substantively enacted rates that it expects to be applicable to the taxable profit (tax loss) of the periods in which it expects the deferred tax asset to be realised or the deferred tax liability to be settled". Moreover the IFRS for SMEs mentions that "the measurement of deferred tax liabilities and deferred tax assets shall reflect the tax consequences that would follow from the manner in which the entity expects, at the reporting date, to recover or settle the carrying amount of the related assets and liabilities". There is an obligation of entity to review the net carrying amount of a deferred tax asset at each reporting date. An entity shall adjust the valuation allowance to reflect the current assessment of future taxable profits. IFRS for SMEs treats recognition of adjustment. Any adjustment shall be recognised in profit or loss, except that an adjustment attributable to an item of income or expense recognised in accordance with this IFRS as other comprehensive income shall also be recognised in other comprehensive income. In the Czech Decree, there is a bookkeeping treatment when the tax rate is amended. If the tax rate is amended, the balance sheet in the deferred tax account must be recalculated and the recognized difference should be charged on an account in account group called - Income tax expense, transfer accounts and income tax provision. As the Czech accounting system introduces neither comprehensive income statement nor other comprehensive income, the adjustments aren't become a part of comprehensive income. 
Valuation allowance, in compliance with IFRS for SMEs, should be recognised against deferred tax assets so that the net carrying amount equals the highest amount that is more likely than not to be recovered based on current or future taxable profit. "An entity shall review the net carrying amount of a deferred tax asset at each reporting date and shall adjust the valuation allowance to reflect the current assessment of future taxable profits. Such adjustment shall be recognised in profit or loss, except that an adjustment attributable to an item of income or expense recognised in accordance with this IFRS as other comprehensive income shall also be recognised in other comprehensive income".

In deferred taxes part, there is important deviation from the regular rule as for prohibition of discount in IFRS for SMEs. An entity shall not discount deferred tax assets and liabilities. As there is no tradition of liabilities to discount in the Czech accounting, there is no obstacle to follow this rule at all.

In the IFRS for SMEs, there is described the uncertainty about whether the tax authorities will accept the amounts of deferred tax reported to them by the entity. "An entity shall measure current and deferred tax assets and liabilities using the probability-weighted average amount of all the possible outcomes, assuming that the tax authorities will review the amounts reported and have full knowledge of all relevant information". In the case that entity pays dividends to its shareholders, it may be required to pay a portion of the dividends to taxation authorities on behalf of shareholders. Then paid or payable amounts to taxation authorities are charged to equity as a part of the dividends.

The part called presentation of deferred taxes in the IFRS for SMEs includes information for allocation in comprehensive income and equity, current or non-current distinction and rules for offsetting. There is an option for an entity where to recognise tax expense: in the same component of total comprehensive income (i.e. continuing operations, discontinued operations, or other comprehensive income) or equity as the transaction or other event that resulted in the tax expense. There is a rule for current or non-current distinction, which is in compliance with IFRS. "When an entity presents current and non-current assets, and current and non-current liabilities, as separate classifications in its statement of financial position, it shall not classify any deferred tax assets (liabilities) as current assets (liabilities)". The offset of deferred tax assets and deferred tax liabilities is allowed only when it has a legally 
enforceable right to set off the amounts and it intends either to settle on a net basis or to realise the asset and settle the liability simultaneously. Recognition of deferred tax assets and liabilities as a long-term item in the balance sheet and similar rules for offsetting is in the Czech accounting standard. A rule for offsetting and current or non-current distinction is respected in the Czech accounting.

Disclosure of deferred tax information should enable users of its financial statements to evaluate the nature and financial effect of the deferred tax consequences of recognised transactions and other events. Therefore an entity shall disclose separately the major components of tax expense (income). As for deferred tax, there should be disclosed: a) the amount of deferred tax expense (income) relating to the origination and reversal of temporary differences; $b$ ) the amount of deferred tax expense (income) relating to changes in tax rates or the imposition of new taxes; c) the effect on deferred tax expense arising from a change in the effect of the possible outcomes of a review by the tax authorities; d) adjustments to deferred tax expense arising from a change in the tax status of the entity or its shareholders; e) any change in the valuation allowance; f) the amount of tax expense relating to changes in accounting policies and errors. There should be separate disclosure of the aggregated current tax and deferred one relating to items that are recognised as items of other comprehensive income, an explanation of the significant differences in amounts presented in the statement of comprehensive income and amounts reported to tax authorities, an explanation of changes in the applicable tax rate(s) compared with the previous reporting period, for each type of temporary difference and for each type of unused tax losses and tax credits (the amount of deferred tax liabilities, deferred tax assets and valuation allowances at the end of the reporting period) and (an analysis of the change in deferred tax liabilities, deferred tax assets and valuation allowances during the period); the expiry date, if any, of temporary differences, unused tax losses and unused tax credits; an explanation of the nature of the potential income tax consequences that would result from the payment of dividends to its shareholders.

The decree in the section called deferred tax method, as describes above, doesn't mention the manner and scope of deferred tax disclosure. There is only a single sentence of its section regulating disclosures in general, section four subsection 39; obligation to disclose detailed specification of deferred tax assets or deferred tax liability in notes on 
conditions that figures are not separately recognized in the balance sheet or income statements.

\section{Conclusion}

Investigating impact of IFRSs on the accounting regulatory system in the Czech Republic, there should be highlighted that IFRS were introduced into the regulatory system gradually as a separate regulatory system for determined group of accounting entities, on the other hand IFRSs have had influence on the development of the local accounting rules during last decade. This article, investigating IAS 12 implementation into Czech accounting regulatory system, implies that IAS 12 implementation was realized in the Czech accounting only partially or incompletely. Beside differences stated in the article, there is an absence of complete parts of investments in subsidiaries, branches and interests in joint ventures, measurement, recognition of current tax and deferred tax. There is also an absence of definitions: tax base of asset, tax base of liabilities, balance sheet approach of liability method, income statement of liability method, temporary differences, taxable temporary differences, deductible temporary differences. Moreover no reference to any rules or accepted accounting principles where the reader is allowed to study terms. IFRS partial implementation may even cause breakdown of the accounting system or may bring entities to the court; moreover entities spent higher costs and may loos confidence by users of accounting information (Žárová - Mejzlík, 2009).

Example of IAS 12 implementation into Czech accounting regulatory system, provide us clear demonstration of wrong philosophy how to reach comparable accounting information. Based on the criticism above, the recommendation is not to continue in partial IFRS implementation but make good rule for entities to allow them to choose either full IFRS or domestic rules applicable in compliance with the approach "think small first”4 (Žárová, 2009).

It was awaited by practitioners and academics too, that the accounting reform process in the Czech Republic will be finalized by issuing the

4 Communication from the Commission to the Council, the European Parliament, the European Economic and Social Committee and the Committee of the Regions "Think Small First" - A "Small Business Act" for Europe $\{\operatorname{SEC}(2008) 2101\}$ $\{$ SEC(2008) 2102\}. 
Žárová, M.: Impact of IFRS on Deferred Taxes Methodology in the Czech Republic and comparison with IFRS for SMEs.

Decree on accounting for business entities and by the Czech Accounting Standard in the period started in 2004. Focusing on the issue of deferred taxation in the Czech Republic, the article brings evidence that the reform was realized only partially and wasn't adopted a holistic approach of IFRS implementation into local national accounting regulatory system. This experiment should become a clear evidence for other European country to carefully think first and prepare long-term plan before IFRS implementation only partly. Better not to make risk of partial IFRS implementation and to destroy the system of local accounting rules.

Using comparative analysis, there might be compliance between Czech accounting rules for deferred taxes and IFRS for SME. Comparison of two systems for deferred taxes brings the evidence of fundamental differences between these two systems. Consequence of the evidence is that rules are used differently for treatment of the same cases. Different accounting treatment for the same case may bring complications to audit too. Preparers of financial statement, auditors and users too could doubt whether to prefer substance of the transaction or legal consequence of the transaction.

\section{References}

[1] Filinger, M. (2009): Deferred Tax and its Conceptual Complexities. $P h D$. thesis. Praha, University of Economics, 2009.

[2] IASB (2009a): International Financial Reporting Standards 2007. London, International Accounting Standards Board, 2009.

[3] IASB (2009b): International Financial Reporting Standard for Small And Medium-Sized Entities. London, IASC Foundation, 2009.

[4] Pelák, J. (2009): Právně-účetní problémy vlastního kapitálu. (In English: Legal and Accounting Issues Concerning Equity.) In: Vašeková, M. - Hora, M. (eds.): Účtovníctvo a audítorstvo v procese svetovej harmonizácie. (In English: Accounting and Auditing in International Harmonization Process.) Bratislava/Praha, Ekonomická univerzita / University of Economics, 2009, pp. 156-159.

[5] Radebaugh, L. - Gray, S. - Black, E. (2006): International Accounting and Multinational Enterprises. New York, Wiley, 2006. 
[6] Skálová, J. - Čouková, P. (2009): Účetní a daňové dopady transakcí $v$ kapitálové společnosti. (In English: Accounting and Taxation in the Companies Limited.) Praha, Wolters Kluwer, 2009.

[7] Žárová, M. (2006): Regulace evropského účetnictví. (In English: Regulation of European Accounting.), Praha, Oeconomica, 2006.

[8] Žárová, M. (2007): Analysis of Hybrid Regulatory Accounting Systems. European Financial and Accounting Journal, 2007, vol. 2, no. 1 , pp. 8-25.

[9] Žárová, M. (2008): Accounting Reform in the Czech Republic. In: McGee, R. W. (ed.): Accounting Reform in Transition and Developing Economies. Miami, Springer, 2008, pp. 89-100.

[10] Žárová, M. - Mejzlík, L. (2009): Have IFRS Positive Impact on the Regulatory Accounting Systems in Continental European Countries? European Financial and Accounting Journal, 2009, vol. 4, no. 1, pp. $5-24$.

[11]Žárová, M. (2009): Dopad směrnice ES na vykazování účetních informací pro malé a střední podniky. (In English: Impact of EC Directive on Disclosure of Accounting Information for Small and Medium-Sized Companies.) Český finanční a účetní časopis, 2009, roč. 4, č. 3, s. 73-77.

[12] Žárová, M. - Procházka, D. - Roe, J. (2011): Financial Reporting in the Czech Republic. Praha, Oeconomica, 2011. 


\title{
Impact of IFRS on Deferred Taxes Methodology in the Czech Republic and comparison with IFRS for SMEs
}

\author{
Marcela ŽÁROVÁ
}

\begin{abstract}
Investigating impact of IFRS on the accounting regulatory system in the Czech Republic, there should be highlighted that IFRS were introduced into the regulatory system gradually as a separate regulatory system for determined group of accounting entities, on the other hand IFRS have had influence on the development of the local accounting rules during last decade. It was awaited by practitioners and academics too, that the process of deferred taxes reform will be finalized by issuing the Decree on accounting for business entities and by the Czech Accounting Standard on deferred taxes. But the reform as for deferred taxes was realized only partially and wasn't adopted a holistic approach of IFRS implementation into local national accounting regulatory system.

Based on the criticism of partial implementation of IAS 12 into local accounting rules, this article is focused on comparability of Czech accounting rules for deferred taxes with IFRS for SME. Conclusion from this investigation might become fundamentals for similar European accounting systems to the Czech Republic.
\end{abstract}

Key words: IAS 12; Deferred tax; IFRS implementation; IFRS for SMEs.

JEL classification: M41. 